\title{
Association of different socio-economic factors with hypertension prevalence, awareness, treatment and control in India: a demographic analysis of NFHS-4
}

\author{
Kaushik Mukhopadhyay, Sonali Mukherjee, Bikramjit Barkandaj, Chandan Chatterjee*
}

Department of Pharmacology, ESI-PGIMSR and ESIC Medical College, Joka, Kolkata, West Bengal, India

Received: 23 December 2018

Accepted: 04 Febuary 2019

*Correspondence:

Dr. Chandan Chatterjee,

E-mail: rivuc2006@gmail.com

Copyright: ( ) the author(s), publisher and licensee Medip Academy. This is an open-access article distributed under the terms of the Creative Commons Attribution Non-Commercial License, which permits unrestricted non-commercial use, distribution, and reproduction in any medium, provided the original work is properly cited.

\begin{abstract}
Background: National Family Health Survey (NHFS) is a periodically conducted survey, which delivers data on health and healthcare of a representative sample of households of India. Studies that have evaluated hypertension awareness, treatment and control and its association with patient level socioeconomic factors are limited in India. The objectives of this study were to determine association of demographic variables like age, sex, habitat, wealth, religion and educational status with prevalence, awareness, treatment, and control of hypertension among rural and urban subjects in different states and union territories of india from NFHS-4 data.

Methods: Data of 803211 subjects were taken from NFHS survey in 36 states and union territories of india, in 20152016. Prevalence of hypertension and its awareness, treatment, and control status and their association with age, sex, habitat, wealth, religion and educational status were determined. Logistic regression was carried out to evaluate the impact of different predictor variables.

Results: Data of 803211 subjects were taken from NFHS survey voluntarily given by them for our project, of which $565705(70.43 \%)$ came from rural population. 103525 of them were male which comprised of $12.89 \%$ and rest $87.11 \%$ were female volunteers in 36 states and union territories of india. Hypertension prevalence, awareness, treatment and control level in India was $17.69 \%, 20.44 \%, 34.37 \%$ and $13.64 \%$ respectively. In general, these parameters were much better in urban population and in female. Although variations were observed between different study sites, they were low with poor education and wealth index.

Conclusions: Hypertension awareness, treatment, and control were mostly low among the male, rural, poor and less educated individuals with large state wise variations.
\end{abstract}

Keywords: Awareness, Blood pressure, Control, Demographic assessment, Hypertension, Treatment

\section{INTRODUCTION}

Hypertension is an important public health problem in India and one of the most important risk factors causing death and morbidity in all populations irrespective of gender, religion, socioeconomic class, education and wealth index. It is defined as systolic blood pressure more than 140 or diastolic blood pressure $90 \mathrm{~mm}$ of $\mathrm{Hg}$ or both as per joint national committee 8 (JNC-8). It leads to most cases of death worldwide in comparison to any other risk factor. ${ }^{1}$ Hypertension is present in $20-30 \%$ of adults in the Indian subcontinent which include Bangladesh and Pakistan reported in different surveys. ${ }^{2-4}$ Hypertension control and treatment are crucial to prevent 
cardiovascular and cerebrovascular complications. ${ }^{5}$ Though availability and regular intake of medicines are essential but multiple factors are associated with control. Physician-related, health-systems-related, social and patient-related factors are all responsible for awareness, control and treatment of hypertension.

NHFS survey is a periodically conducted survey, which delivers data on health and healthcare of a representative sample. Total 6,01,509 households, 1,12,122 men and $6,99,686$ women were interviewed from numerus primary sampling units (PSU). ${ }^{6}$ It included rural areas and census enumeration blocks (CEB) in urban areas all over India (NFHS-4, 2015-16). In this article authors have made an effort to understand hypertension, and its association with patient level socioeconomic factors such as household age, sex, habitat, wealth, religion and educational status in all states and union territories of india.

\section{METHODS}

Authors requested NFHS-4 dataset from the demographic and health surveys (DHS) online archive and secondary data analysis was performed with due permission. ${ }^{7,8}$

\section{Case definition}

A case is defined as a subject with systolic blood pressure more than $140 \mathrm{~mm}$ of $\mathrm{Hg}$ or diastolic blood pressure $90 \mathrm{~mm}$ of $\mathrm{Hg}$ or both as per Joint national committee 8 (JNC 8) and those diagnosed beforehand as per same definition and under diet control or /and treatment with one or more antihypertensive drugs. ${ }^{9}$ Those patients who were previously diagnosed and aware of raised BP ( $\geq 140 \mathrm{~mm} \mathrm{Hg}$ systolic and/or $\geq 90 \mathrm{~mm} \mathrm{Hg}$ diastolic) were put under the category of awareness of hypertension. Treatment group was defined as the patients who were on BP-lowering medicines (aware or unaware). People with hypertension who had BP of $<140 / 90 \mathrm{~mm} \mathrm{Hg}$ was categorized as control.

\section{Study Parameters}

Hypertension awareness, treatment, control, baseline characteristics and demographic pattern are defined by descriptive statistics. Prevalence of hypertension and its awareness, treatment, and control status and their association with wealth, education was determined. It was also stratified by state and union territory wise distribution within India.

Education was categorized as primary education, secondary, no education and higher education in present study. Wealth index is defined as a composite measure of a household's cumulative living standard. It is calculated using easy-to-collect data like ingredients used for construction of a housing, or a household's ownership of selected assets, such as televisions and bicycles, and types of sanitation and water supply. ${ }^{10}$

\section{Analysis plan}

The prevalence of hypertension, awareness, treatment, and control has also been categorized by residence (urban/rural), age and sex (men/women). Hypertension and its different determinants have been examined using justified logistic regression model at various levels. The list of each variable that was included is summarized in results section.

\section{Statistical analysis}

All statistical analyses were carried out by $\mathrm{R}$ version 3.3.3 R Studio version 1.0.136 ( $\mathrm{R}$ foundation) statistical software (Language). $\mathrm{P}<0.05$ was considered as statistically significant. Logistic regression was carried out to evaluate the association of different predictor variables.

\section{RESULTS}

Data of 803211 subjects were taken from NFHS survey voluntarily given by them for present project, of which $565705(70.43 \%)$ came from rural population. 103525 of them were male which comprised of $12.89 \%$ and rest were $87.11 \%$ made up of huge chunk of female volunteers in 36 states and union territories of India, in 2015.

Table 1 shows number and percentage of participants both male and female rural and urban from each state of our country. Mean age of study participants at recruitment was 29.86 ( $\mathrm{SD}=9.776$ ). Highest number of people participated from Uttar Pradesh (110600) whereas the lowest one from Chandigarh (866). Though the lowest rural population participated from Delhi (1.52\%), Chandigarh a union territory and a capital of Haryana contributed only $4.5 \%$ of the population. Maximum rural population $(92.35 \%)$ participated from Himachal Pradesh but Assam (86.37\%), Bihar (86.11\%) and Odisha $(79.91 \%)$ contributed significant number of rural populations in present study.

Reasonable prevalence of Hypertension $17.69 \%$ was found among study population in our country. Though highest prevalence was found in Tamil Nadu (30.35\%), Mean systolic $(>120 \mathrm{~mm}$ of $\mathrm{Hg})$ and diastolic blood pressure $(>80 \mathrm{~mm}$ of $\mathrm{Hg}$ ) were found higher is north east states like Arunachal Pradesh, Assam, Sikkim and Nagaland. 


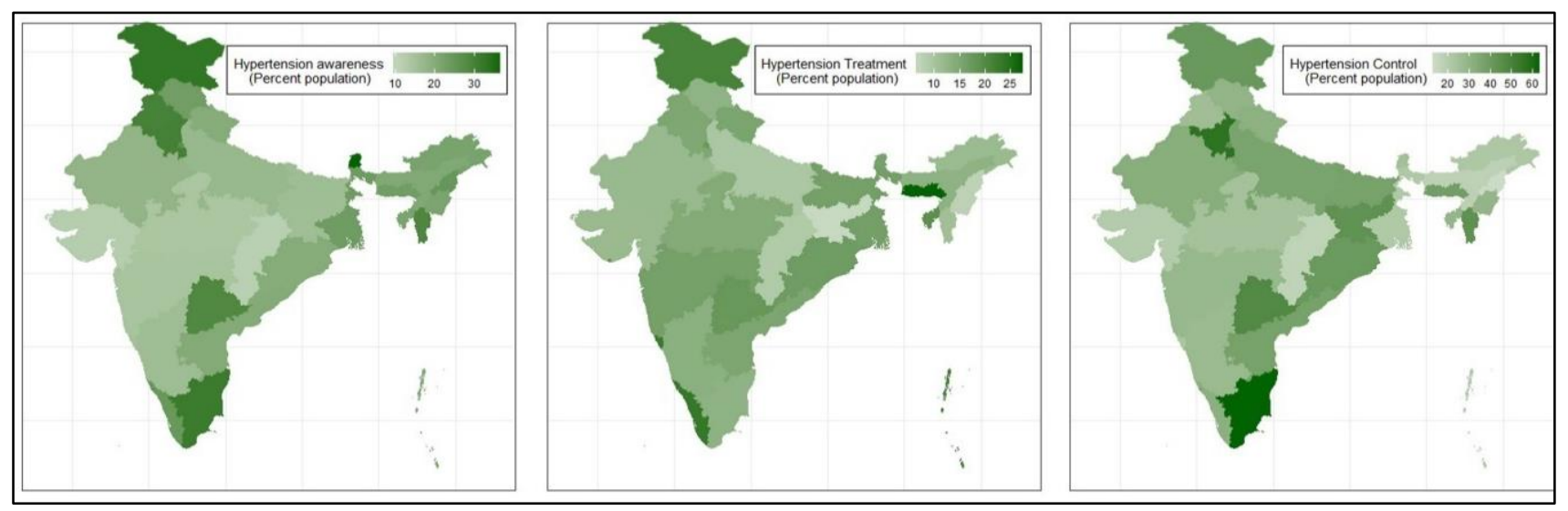

Figure 1: Choropleth map showing region wise distribution of hypertension awareness, treatment and control.

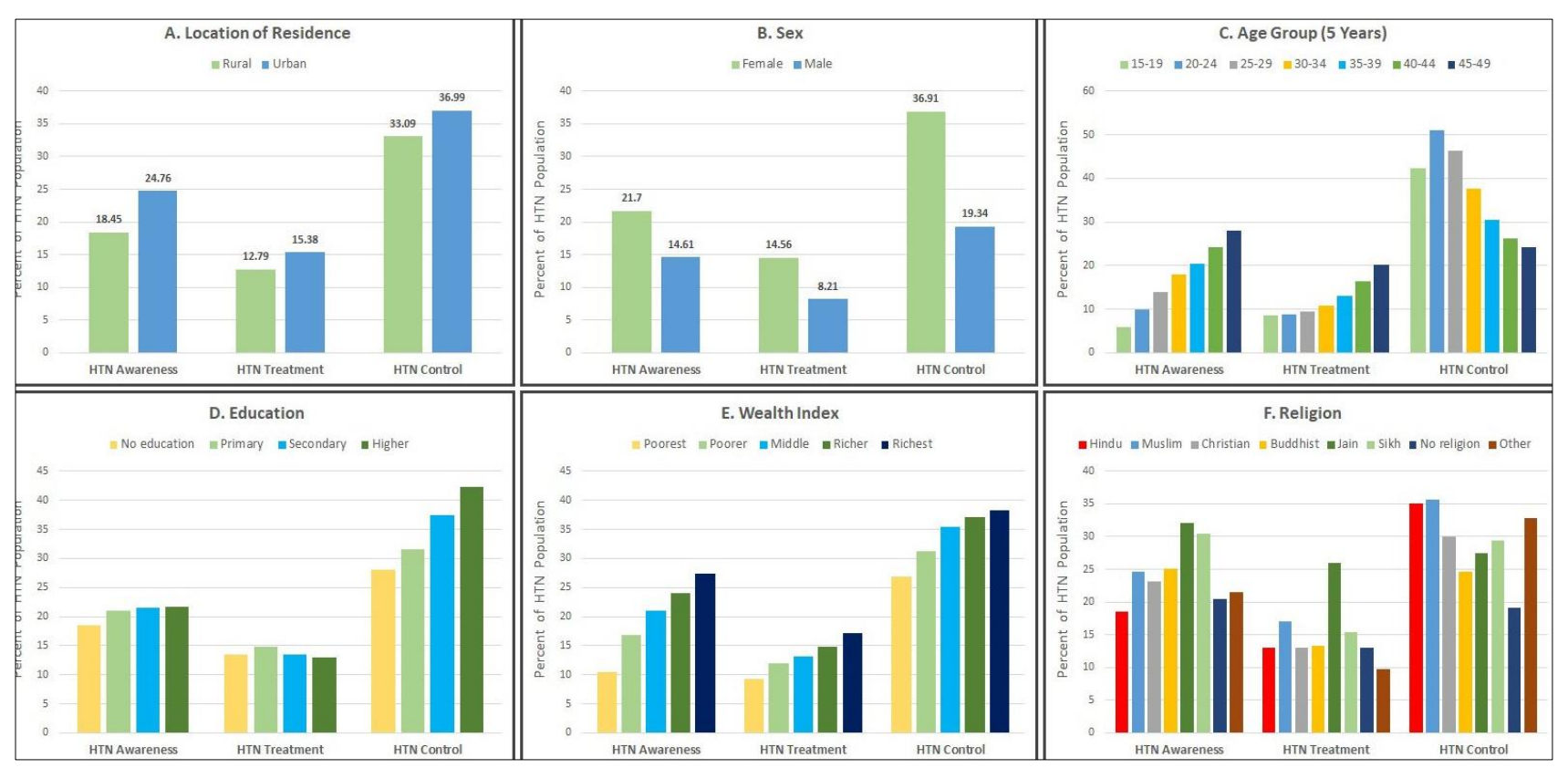

Figure 2: Bar diagram showing effect of different socio-economic factors on hypertension awareness, treatment and control.

Choropleth map was used to demonstrate hypertension awareness, treatment, and control showing state and union-based territories wise distribution highlighted in (Figure 1). Hypertension awareness was maximum in Sikkim (37.73\%) overall being $20.44 \%$ in India and least in Daman and Diu $8.75 \%$.

Prevalence of all people in present study population undergoing hypertensive treatment was $13.64 \%$ whereas Jharkhand contributed least number of treated cases $(6.24 \%)$ and most found in Meghalaya (27.08\%). Control of hypertension was highest in Tamil Nadu $63.04 \%$ and least in Nagaland $13.72 \%$ whereas overall in India it came around $34.37 \%$. Chhattisgarh had shown exceptionally low awareness $(11.16 \%)$, treatment $(9.1 \%)$ and control $(17.6 \%)$ level in comparison to most of the states. In rural vs. urban population, awareness, treatment and control of hypertension were much better in the later ( $\mathrm{P}<0.001$, chi-square test) reflected in (Figure 2A).
Women were more responsive in compared to men, in terms of hypertension awareness $(21.7 \%$ vs. $14.61 \%)$, treatment $(14.56 \%$ vs. $8.21 \%)$, and control (36.91\% vs. $19.34 \%)$ (P <0.001, chi-square test). (Figure 2B) A remarkably attractive pattern was observed while comparing hypertension awareness, treatment, and control in different age groups as vividly depicted in (Figure 2C). Hypertension awareness and treatment improve with increase in age. In other words, older population were significantly more aware about the fact that they had hypertension and were more often treated $(\mathrm{P}$ $<0.001$, chi-square test). But hypertension control reduces with age which was contrary to our previous observations. (Figure 2C)

Although variations were observed between different study sites, over- all the level of awareness control and treatment were low with poor education (Figure 2D) and low wealth index (Figure 2E). Certain observations were 
noticed when these parameters were compared in respect to religion. Hypertension control was comparable in Hindu and Muslim populations, but awareness and treatment were noticeably better in Muslims. (Figure 2F).
Multivariate logistic regression analysis depicted the effect of different predictor demographic variables on the Hypertension prevalence, awareness, treatment and control (Table 2).

Table 1: Demographic pattern of study participants in all states and union territories of india.

\begin{tabular}{|c|c|c|c|c|c|c|c|}
\hline $\begin{array}{l}\text { State / Union } \\
\text { territory }\end{array}$ & $\mathbf{N}$ & $\begin{array}{l}\text { Rural } \\
(\%)\end{array}$ & Male (\%) & Age (SD) & $\begin{array}{l}\text { Hypertension } \\
(\%)\end{array}$ & $\begin{array}{l}\text { Systolic } \\
\text { BP } \\
\text { Mean (SD) }\end{array}$ & $\begin{array}{l}\text { Diastolic } \\
\text { BP } \\
\text { Mean (SD) }\end{array}$ \\
\hline $\begin{array}{l}\text { Andaman and } \\
\text { Nicobar } \\
\text { Island }\end{array}$ & 3222 & $2652(82.31)$ & $411(12.76)$ & $31.42(9.63)$ & $631(19.71)$ & $115.52(15.23)$ & $78.47(12.71)$ \\
\hline $\begin{array}{l}\text { Andhra } \\
\text { Pradesh }\end{array}$ & 11827 & 8035 (67.94) & $1399(11.83)$ & $31.34(9.73)$ & $2108(19.08)$ & $112.56(14.86)$ & $77.56(14.57)$ \\
\hline $\begin{array}{l}\text { Arunachal } \\
\text { Pradesh }\end{array}$ & 16224 & 12664 (78.06) & 1930 (11.9) & $30.45(9.65)$ & 4067 (25.87) & $120.4(16.28)$ & $81.65(18.04)$ \\
\hline Assam & 32307 & $27905(86.37)$ & $3860(11.95)$ & $30.14(9.67)$ & $7519(23.82)$ & $121.57(15.68)$ & $81.2(13.6)$ \\
\hline Bihar & 51245 & $44127(86.11)$ & $5433(10.6)$ & $28.75(9.76)$ & $6017(11.88)$ & $113.11(13.23)$ & $76(16.12)$ \\
\hline Chandigarh & 866 & $39(4.5)$ & $120(13.86)$ & $30.71(9.78)$ & $144(18.53)$ & $113.02(14.96)$ & $76.46(14.34)$ \\
\hline Chhattisgarh & 28701 & $20692(72.1)$ & $3529(12.3)$ & $29.63(9.87)$ & 3804 (13.39) & $115.77(14.41)$ & $77.74(14.92)$ \\
\hline $\begin{array}{l}\text { Dadra and } \\
\text { Nagar Haveli }\end{array}$ & 1002 & $548(54.69)$ & $206(20.56)$ & $29.15(9.23)$ & 126 & 113.12 & $78.12(18.24)$ \\
\hline $\begin{array}{l}\text { Daman and } \\
\text { Diu }\end{array}$ & 1825 & $680(37.26)$ & 432 (23.67) & $29.59(9.31)$ & 209 (12.2) & 116.08 (13.38) & 78.37 (13.1) \\
\hline Delhi & 6586 & 2) & 672 & 29. & & $109.39(15.42)$ & 75.35 (13.99) \\
\hline Goa & 2463 & $1259(51.12)$ & 767 & 32.07 (9.9) & 367( & $115.78(13.9)$ & $77.85(11.65)$ \\
\hline Gujarat & 28506 & $18160(63.71)$ & $5574(19.55)$ & $30.42(9.77)$ & 4190 & $115.71(14.44)$ & $78.19(16.65)$ \\
\hline Haryana & 25035 & & $3381(13.51)$ & & & $118.48(13.13)$ & $78.69(14.24)$ \\
\hline $\begin{array}{l}\text { Himachal } \\
\text { Pradesh }\end{array}$ & 12114 & $11187(92.35)$ & $2185(18.04)$ & $31.47(9.75)$ & $2612(22.06)$ & 117.19 (14.7) & $80.41(18.21)$ \\
\hline $\begin{array}{l}\text { Jammu and } \\
\text { Kashmir }\end{array}$ & 29384 & $23829(81.1)$ & 558 & $(9.52)$ & 6471 & $118.72(1$ & $78.46(16.85)$ \\
\hline Jharkhand & 3 & & 62) & 2 & & 82) & 7.64) \\
\hline Karnataka & 30051 & $19763(65.76)$ & $3760(12.51)$ & $5(9.62)$ & & $116.22(14$ & $78.27(15.98)$ \\
\hline Kerala & & & & & & $114.99(14.28)$ & $75.65(15.56)$ \\
\hline Lakshadv & 1226 & & & & & & $2(13.82)$ \\
\hline $\begin{array}{l}\text { Madhya } \\
\text { Pradesh }\end{array}$ & 72299 & $50600(69.99)$ & $9496(13.13)$ & $29.62(9.85)$ & 9503 (13. & $115.1(13.46)$ & 14.78) \\
\hline Maharashtra & 33915 & 212 & .14) & $30.36(9.71)$ & 521 & $112.93(14.27)$ & $77.31(13.94)$ \\
\hline Manipur & 15340 & $2(63.57)$ & 1747 (11.39) & $30.71(9.66)$ & 30 & $117.69(13.94)$ & $79.97(13.08)$ \\
\hline Meghalaya & 10346 & $8142(78.7)$ & $1144(11.06)$ & $29.14(9.75)$ & $1824(18.02)$ & $115.66(15.08)$ & $76.66(15.39)$ \\
\hline Mizoram & 13896 & $6891(49.59)$ & $1617(11.64)$ & $30.36(9.48)$ & $0.11)$ & $115.01(13.03)$ & $78.8(15.28)$ \\
\hline Nagaland & 12230 & $8036(65.71)$ & $1440(11.77)$ & $30.47(9.65)$ & & $120.59(16.59)$ & $81.59(16.82)$ \\
\hline Odisha & 37930 & $30311(79.91)$ & 4209 (11.1) & $30.42(9.87)$ & $6637(17.8)$ & $115.12(14.3)$ & $77.39(15.6)$ \\
\hline Puducherry & 4622 & $1138(24.62)$ & $610(13.2)$ & $31.53(9.79)$ & $1368(29.71)$ & $115.98(14.32)$ & $78.28(12.19)$ \\
\hline Punjab & 22511 & $14195(63.06)$ & $3027(13.45)$ & $30.75(9.55)$ & $5127(23.01)$ & $120.36(14.67)$ & $80.1(12.76)$ \\
\hline Rajasthan & 47857 & $34702(72.51)$ & $5892(12.31)$ & $29.11(9.67)$ & $6123(12.93)$ & $115.57(12.95)$ & $77.09(14.61)$ \\
\hline Sikkim & 6094 & $4451(73.04)$ & $801(13.14)$ & $30.07(9.31)$ & $1669(27.51)$ & $122.28(15.05)$ & $82.09(16.41)$ \\
\hline Tamil Nadu & 33614 & $18558(55.21)$ & $4794(14.26)$ & $31.38(9.8)$ & $10080(30.35)$ & $114.41(14.54)$ & $77.87(14.2)$ \\
\hline Telangana & 8621 & $5466(63.4)$ & $1054(12.23)$ & $30.53(9.59)$ & $1815(22.54)$ & $111.64(15.78)$ & 76.99 (14.87) \\
\hline Tripura & 5625 & $4010(71.29)$ & $821(14.6)$ & $30.75(9.69)$ & $1101(19.96)$ & $117.97(13.66)$ & $80.31(13.87)$ \\
\hline Uttar Pradesh & 110600 & $79975(72.31)$ & $12939(11.7)$ & $28.63(9.84)$ & $15795(14.43)$ & $114.98(13.29)$ & $77.1(13.6)$ \\
\hline Uttarakhand & 19294 & $13405(69.48)$ & $1994(10.33)$ & $29.51(9.82)$ & $3165(16.73)$ & $115.78(13.87)$ & $78.34(15.36)$ \\
\hline West Bengal & 20070 & 14485 (72.17) & $2402(11.97)$ & $30.28(9.86)$ & $3172(16.22)$ & $118.65(14.38)$ & $79.13(14.12)$ \\
\hline Overall & 803211 & $565705(70.43)$ & $103525(12.89)$ & $29.86(9.77)$ & $139343(17.69)$ & $115.96(14.28)$ & $78.04(15.09)$ \\
\hline
\end{tabular}


Table 2: Logistic regression showing the effect of predictor variables on the Hypertension prevalence, awareness, treatment and control.

\begin{tabular}{|c|c|c|c|c|c|}
\hline \multicolumn{2}{|c|}{$\begin{array}{l}\text { Background } \\
\text { characteristic }\end{array}$} & \multirow{2}{*}{$\begin{array}{l}\text { Hypertension } \\
\text { prevalence } \\
1.072 * * * \\
(1.071,1.073)\end{array}$} & \multirow{2}{*}{$\begin{array}{l}\text { Hypertension } \\
\text { awareness } \\
1.053 * * * \\
(1.051,1.056)\end{array}$} & \multirow{2}{*}{$\begin{array}{l}\text { Hypertension } \\
\text { treatment } \\
1.043 * * * \\
(1.04,1.045)\end{array}$} & \multirow{2}{*}{$\begin{array}{l}\text { Hypertension } \\
\text { control } \\
0.957 * * * \\
(0.956,0.959)\end{array}$} \\
\hline Age & $\begin{array}{l}\text { Age in years } \\
(+1 \text { Year })\end{array}$ & & & & \\
\hline \multirow[b]{2}{*}{$\begin{array}{l}\text { Smoking } \\
\text { Habit }\end{array}$} & Non-smoker ® & 1.00 & 1.00 & 1.00 & 1.00 \\
\hline & Smoker & $\begin{array}{l}0.954 * * \\
(0.922,0.986)\end{array}$ & $\begin{array}{l}1.132 * * \\
(1.035,1.238)\end{array}$ & $\begin{array}{l}0.970 \\
(0.881,1.067)\end{array}$ & $\begin{array}{l}1.338 * * * \\
(1.249,1.434)\end{array}$ \\
\hline \multirow[b]{2}{*}{ Sex } & Female ${ }^{\circledR}$ & 1.00 & 1.00 & 1.00 & 1.00 \\
\hline & Male & $\begin{array}{l}1.176^{* * * *} \\
(1.151,1.202)\end{array}$ & $\begin{array}{l}0.572 * * * \\
(0.538,0.607)\end{array}$ & $\begin{array}{l}0.517 * * * \\
(0.484,0.552)\end{array}$ & $\begin{array}{l}0.336 * * * \\
(0.32,0.352)\end{array}$ \\
\hline \multirow[b]{2}{*}{ Residence } & Rural ® & 1.00 & 1.00 & 1.00 & 1.00 \\
\hline & Urban & $\begin{array}{l}1.015^{*} \\
(0.998,1.032)\end{array}$ & $\begin{array}{l}1.058^{*} \\
(1.013,1.106)\end{array}$ & $\begin{array}{l}0.990 \\
(0.95,1.031)\end{array}$ & $\begin{array}{l}1.035^{*} \\
(1.003,1.067)\end{array}$ \\
\hline \multirow{4}{*}{$\begin{array}{l}\text { Education } \\
\text { level }\end{array}$} & No education $₫$ & 1.00 & 1.00 & 1.00 & 1.00 \\
\hline & Primary & $\begin{array}{l}1.112 * * * \\
(1.087,1.137)\end{array}$ & $\begin{array}{l}1.196 * * * \\
(1.127,1.269)\end{array}$ & $\begin{array}{l}1.19 * * * \\
(1.125,1.258)\end{array}$ & $\begin{array}{l}1.065 * * * \\
(1.02,1.112)\end{array}$ \\
\hline & Secondary & $\begin{array}{l}1.117 * * * \\
(1.096,1.139)\end{array}$ & $\begin{array}{l}1.317 * * * \\
(1.252,1.385)\end{array}$ & $\begin{array}{l}1.166 * * * \\
(1.111,1.222)\end{array}$ & $\begin{array}{l}1.158 * * * \\
(1.117,1.199)\end{array}$ \\
\hline & Higher & $\begin{array}{l}1.082 * * * \\
(1.052,1.113)\end{array}$ & $\begin{array}{l}1.311 * * * \\
(1.213,1.417)\end{array}$ & $\begin{array}{l}1.099 * \\
(1.022,1.181)\end{array}$ & $\begin{array}{l}1.319 * * * \\
(1.252,1.39)\end{array}$ \\
\hline \multirow{4}{*}{ Religion } & Hindu® & 1.00 & 1.00 & 1.00 & 1.00 \\
\hline & Muslim & $\begin{array}{l}1.246 * * * \\
(1.221,1.270)\end{array}$ & $\begin{array}{l}1.541 * * * \\
(1.463,1.623)\end{array}$ & $\begin{array}{l}1.436 * * * \\
(1.369,1.505)\end{array}$ & $\begin{array}{l}0.972 \\
(0.937,1.009)\end{array}$ \\
\hline & Christian & $\begin{array}{l}1.179 * * * \\
(1.149,1.209)\end{array}$ & $\begin{array}{l}1.265 * * * \\
(1.186,1.349)\end{array}$ & $\begin{array}{l}0.983 \\
(0.92,1.049)\end{array}$ & $\begin{array}{l}0.725 * * * \\
(0.691,0.761)\end{array}$ \\
\hline & Other & $\begin{array}{l}1.386 * * * \\
(1.346,1.427)\end{array}$ & $\begin{array}{l}1.454 * * * \\
(1.357,1.558)\end{array}$ & $\begin{array}{l}0.997 \\
(0.927,1.071)\end{array}$ & $\begin{array}{l}0.710 * * * \\
(0.671,0.750)\end{array}$ \\
\hline \multirow{5}{*}{$\begin{array}{l}\text { Wealth } \\
\text { Index }\end{array}$} & Poorest $®$ & 1.00 & 1.00 & 1.00 & 1.00 \\
\hline & Poorer & $\begin{array}{l}1.126 * * * \\
(1.100,1.152)\end{array}$ & $\begin{array}{l}1.600 * * * \\
(1.485,1.725)\end{array}$ & $\begin{array}{l}1.251 * * * \\
(1.169,1.34)\end{array}$ & $\begin{array}{l}1.277 * * * \\
(1.218,1.339)\end{array}$ \\
\hline & Middle & $\begin{array}{l}1.274 * * * \\
(1.245,1.304)\end{array}$ & $\begin{array}{l}1.984 * * * \\
(1.843,2.136)\end{array}$ & $\begin{array}{l}1.379 * * * \\
(1.29,1.476)\end{array}$ & $\begin{array}{l}1.547 * * * \\
(1.476,1.621)\end{array}$ \\
\hline & Richer & $\begin{array}{l}1.448 * * * \\
(1.413,1.484)\end{array}$ & $\begin{array}{l}2.225 * * * \\
(2.063,2.401)\end{array}$ & $\begin{array}{l}1.546 * * * \\
(1.443,1.657)\end{array}$ & $\begin{array}{l}1.653 * * * \\
(1.574,1.736)\end{array}$ \\
\hline & Richest & $\begin{array}{l}1.462 * * * \\
(1.423,1.503)\end{array}$ & $\begin{array}{l}2.505 * * * \\
(2.310,2.717)\end{array}$ & $\begin{array}{l}1.822 * * * \\
(1.692,1.961)\end{array}$ & $\begin{array}{l}1.756 * * * \\
(1.665,1.852)\end{array}$ \\
\hline
\end{tabular}

Abbreviations: ${ }^{\circledR}$ - Reference group, Significance codes: ‘***’ 0.001 '**’ $0.01^{\text {'*’ }} 0.05$

\section{DISCUSSION}

This study shows that there are large variations in prevalence of hypertension within different states and Union Territories of India. Authors have noticed that prevalence of hypertension is higher in urban locality, among older people and, among subjects with greater wealth, and higher educational status. Hypertension awareness, treatment, and control are better in women, and significantly lower in rural participants and those with low wealth index and educational status. Authors did not evaluate health policy issues as well as other socioeconomic markers of low hypertension treatment and control such as availability or access to treatment, costs of drug, provision of free medicines, and health insurance status, and hence cannot comment on their relevance.

World health organization has reported that hypertension prevalence is the highest in low and lower-middle income countries as compared to upper-middle and high-income countries. ${ }^{1}$ Authors have shown that hypertension is common in India, with state wise variations (Table 1). Focus should be given to vulnerable groups to better control of hypertension in the regions of poor awareness and control. CVS morbidity and mortality, which are sequelae to poor hypertension management can only be reduced by adequate intervention. India, China, Russia, Pakistan, and Indonesia have reported that high BP is the most important risk factor for global mortality. This is 
published in global burden of diseases study. ${ }^{2,3}$ Limited data are available from South Asia where high BP is estimated to cause to more than a million deaths annually. ${ }^{11-13}$ South Asian region is the most populous in the world and our data, which may be nationally representative, show a poor status of hypertension management. ${ }^{14}$ Hypertension awareness, treatment, and control were $48.2 \%, 42.8 \%$, and $12.8 \%$ in Malaysia while in China it was $41.6 \%, 34.4 \%$, and $8.2 \%$, respectively. In present study India showed $20.44 \%, 13.64 \%$ and $34.37 \%$ respectively which showed hypertension control was best among the three. In Pure study, hypertension prevalence in South-East Asia was more in low socioeconomic status subjects whereas it showed an opposite result in South Asians. Education related information in both areas were similar. ${ }^{15}$ Relationship with education was one of the prime highlights of our survey shown in (Figure 2 and Table 2). There are only few studies that have reported association of various socioeconomic indicators with hypertension treatment and control which have been demonstrated in our survey. ${ }^{16}$

Multiple reasons are associated with better hypertension awareness and include national health and education policies and health services-related factors. In the Pure study, it has been reported that despite a lower prevalence of risk factors in low-income countries (India, Bangladesh, Pakistan, and Zimbabwe), strokes and coronary heart disease related mortality was greater. ${ }^{17}$ This suggests that the higher cardiovascular death rated may be due to lack of adequate health care facilities, inadequate primary prevention (hypertension, cessation of smoking habit) as well as poor management of diseases. ${ }^{18}$ Present study survey confirms poor hypertension awareness, treatment and control status in India. Hypertension management is a marker of overall cardiovascular risk factor management and could be a marker of strength of health systems. World health organization and united nations has targeted $25 \%$ reduction in non-communicable mortality by 2025 (25x 25 strategy) and has focused on hypertension prevention and management as an important means to achieve this target. ${ }^{19}$ Our results indicate that it is important to improve hypertension treatment and control status in different states and union territories in order to achieve these targets.

Previous studies on healthcare access and utilization in low and lower-middle income countries have reported multiple social and economic barriers. ${ }^{20} \mathrm{~A}$ qualitative study among rural women with hypertension in India highlighted problems of access and costs and also highlighted use of more expensive medicines by physicians. ${ }^{21}$ Similar studies in urban patients with hypertension in India and Pakistan reported lack of family and peer support, financial issues, lack of understanding of nature of disease, and physician inertia as factors responsible for low adherence to antihypertensive treatment and poor control. ${ }^{22,23}$
Present study data survey has its strengths and limitations. Authors have covered all states and union territories and tried to cover most of the demographic findings in comparison to a south Asian study and Pure study which were not nationally representative. ${ }^{18}$ Authors have reported lower hypertension awareness, treatment, but better control in lower age groups. Inability to show chronological trend of hypertension prevalence due to lack of evaluable data from NHFS 1, 2 and 3 is one of the major limitations of this study.

On the other hand, this is going to be one of the largest surveys on hypertension prevalence in India and provides information on important determinants of awareness, treatment, and control.

\section{CONCLUSION}

In conclusion, this study shows that hypertension is common in India, with large state wise variations in hypertension awareness, treatment, and control. However, the rates of these parameters are low among the rural, the poor, and less educated individuals. Focus on these vulnerable groups to better control hypertension in different states and union territories of India is urgently required to reduce cardiovascular disease morbidity and mortality.

\section{Funding: No funding sources Conflict of interest: None declared \\ Ethical approval: The study was approved by the Institutional Ethics Committee}

\section{REFERENCES}

1. World Health Organization. Global status report of non-communicable diseases 2014. World Health Organization: Geneva, 2014.

2. Anchala R, Kannuri NK, Pant H, Khan H, Franco $\mathrm{OH}, \mathrm{Di}$ Angelantonio E et al. Hypertension in India: a systematic review and meta-analysis of prevalence, awareness, and control of hypertension. J Hypertens. 2014; 32:1170-7.

3. Gupta R. Urban rural convergence of hypertension in India. J Hum Hypertens. 2016; 30:79-82.

4. Deedwania PC, Gupta R. In: Hypertension in South Asians. In Black HR, Elliott WJ, eds. Hypertension: A Companion Textbook to Braunwald's Heart Disease, 2nd ed. WB New York, Saunders: 2012;373-378.

5. Blood pressure lowering treatment trialists' collaboration. Effects of different blood-pressurelowering regimens on major cardiovascular events: results of prospectively-designed overviews of randomised trials. Lancet. 2003;362(9395):1527-35.

6. Bansod D, Paswan B, Lhungdim H. Increasing Trends of Caesarean Deliveries in India: Does Private Sector Contributes It?.2018.

7. National family health survey. Available at: http://rchiips.org/nfhs/. 
8. The DHS Program - Quality information to plan, monitor and improve population, health, and nutrition programs. Available at: https://dhsprogram.com/.

9. Armstrong, C. Joint national committee. JNC8 guidelines for the management of hypertension in adults. Am Fam Physic. 214;90(7), 503-4.

10. The DHS program-Wealth index construction. Available at: https://www.dhsprogram.com/topics/wealthindex/Wealth-Index-Construction.cfm.

11. Shepard D, VanderZanden A, Moran A, Naghavi M, Murray C, Roth G. Ischemic heart disease worldwide, 1990 to 2013: estimates from the global burden of disease study 2013. Circulation: Cardiovasc Quality Outcomes. 2015 Jul;8(4):455-6.

12. Roth GA, Huffman MD, Moran AE, Feigin V, Mensah GA, Naghavi M, et al. Global and regional patterns in cardiovascular mortality from 1990 to 2013. Circulation. 2015;132:1667-8.

13. Collaborators CO. Global, regional, and national age-sex specific all-cause and cause-specific mortality for 240 causes of death, 1990-2013: a systematic analysis for the Global burden of disease study 2013. Lancet. 2015;385(9963):117-71.

14. Corsi DJ, Subramanian SV, Chow CK, McKee M, Chifamba J, Dagenais G, et al. Prospective urban rural epidemiology study: baseline characteristics of the household sample and comparative analyses with national data in 17 countries. Am Heart J. 2013;166(4):636-46.

15. Chow CK, Teo KK, Rangarajan S, Islam S, Gupta $\mathrm{R}$, Avezum A et al. Prospective urban rural epidemiology study Investigators. Prevalence, awareness, treatment, and control of hypertension in rural and urban communities in high-, middle-, and low-income countries. JAMA 2013;310:959-68.

16. Dans A, Ng N, Varghese C, Tai ES, Firestone R, Bonita R. The rise of chronic non-communicable diseases in southeast Asia: time for action. Lancet. 2011;377:680-9.
17. Yusuf S, Rangarajan S, Teo K, Islam S, Li W, Liu L et al. PURE investigators. Cardiovascular risk and events in 17 low-, middle-, and high-income countries. N Engl J Med. 2014;371:818-27.

18. Spencer S. Lessons from the PURE study. Glob Cardiol Sci Pract. 2014; 2014(4):379-81.

19. Adler AJ, Prabhakaran D, Bovet P, Kazi DS, Mancia G, Mungal-Singh V et al. Reducing cardiovascular mortality through prevention and management of raised blood pressure: a World Heart Federation road- map. Glob Heart. 2015 Jun;10(2):111-22.

20. Khatib R, Schwalm JD, Yusuf S, Haynes RB, McKee M, Khan M, et al. Patient and healthcare provider barriers to hypertension awareness, treatment and follow up: a systematic review and meta-analysis of qualitative and quantitative studies. PloS One. 2014 Jan 15;9(1):e84238

21. Gupta R, Gupta S. Socioeconomic factors and hypertension awareness, treatment and control in India. In:Muruganathan A (ed), Hypertension Society of India Manual of Hypertension. Jaypee Brothers Medical Publishers: New Delhi, 2016:1221.

22. Kusuma YS. Perceptions on hypertension among migrants in Delhi, India: a qualitative study. BMC Public Health. 2009 Dec;9(1):267.

23. Hashmi SK, Afridi MB, Abbas K, Sajwani RA, Saleheen D, Frossard PM et al. Factors associated with adherence to anti-hypertensive treatment in Pakistan. PLoS One 2007;2:e280.

Cite this article as: Mukhopadhyay K, Mukherjee S, Barkandaj B, Chatterjee C. Association of different socio-economic factors with hypertension prevalence, awareness, treatment and control in India: a demographic analysis of NFHS-4. Int J Res Med Sci 2019;7:815-21. 